\title{
Evaluation of Palladium-Based Sorbents for Trace Mercury Removal in Electricity Generation
}

\author{
Christopher L. Munson 1*, Pradeep Indrakanti1, Massood Ramezan1, Evan Granite², \\ Jenny Tennant ${ }^{2}$ \\ ${ }^{1}$ Leonardo Technologies, Inc., Pittsburgh, USA \\ ${ }^{2}$ Department of Energy, National Energy Technology Laboratory (DOE/NETL), Pittsburgh, USA \\ Email: ${ }^{*}$ christopher.munson@contr.netl.doe.gov, pindrakanti@lti-global.com, \\ massood.ramezan@contr.netl.doe.gov, evan.granite@netl.doe.gov, jenny.tennant@netl.doe.gov
}

Received 15 September 2014; revised 21 October 2014; accepted 25 November 2014

Copyright (C) 2014 by authors and Scientific Research Publishing Inc.

This work is licensed under the Creative Commons Attribution International License (CC BY). http://creativecommons.org/licenses/by/4.0/

(c) (i) Open Access

\section{Abstract}

The development of warm-gas cleanup (WGCU) systems for synthesis gas (syngas) cleanup in integrated gasification combined cycle (IGCC) power plants has the potential to lower the costs of generating power. WGCU includes the removal of mercury $(\mathrm{Hg})$, present in coal, from the syngas. Carbon-based sorbents used for $\mathrm{Hg}$ removal are not suitable for high-temperature $\mathrm{Hg}$ removal in conjunction with the WGCU. The US Department of Energy's National Energy Technology Laboratory's (DOE/NETL) Office of Research \& Development (ORD) has been developing various sorbent alternatives to address the problem of high-temperature $\mathrm{Hg}$ removal. This study presents analysis of the capture of $\mathrm{Hg}$ from syngas streams as a polishing step to attain US Environmental Protection Agency (EPA) Mercury and Air Toxics Standards (MATS) requirements for $\mathrm{Hg}\left(0.003 \mathrm{lb} / \mathrm{GWh}_{\text {gross }}\right.$ for new IGCC plants) using palladium (Pd) adsorbent being tested by DOE/NETL in association with Johnson Matthey (JM). For the present study, it was assumed that syngas is already cleaned to 5 parts per billion by weight $\left(\mathrm{ppb}_{\mathrm{w}}\right) \mathrm{Hg}$, and the Pd sorbent technology is used as a polishing step to achieve the EPA MATS requirements $\left(0.003 \mathrm{lb} / \mathrm{GWh}_{\text {gross, }}\right.$, equivalent to $2 \mathrm{ppb}_{\mathrm{w}}$ given representative process configuration and material flows). The incremental cost of $\mathrm{Hg}$ polishing and the additional capital cost needed were estimated for several scenarios/cases. These cases were differentiated by variance in the following parameters, which are important because they have direct impacts on additional capital costs $(\$ / \mathrm{kW})$, and in turn impacts on the levelized cost of electricity (LCOE): 1) Pd cost (varied from $\$ 4,000$ to $\$ 12,000 / \mathbf{l b}$ Pd); 2) Gas hourly space velocity (SV) (varied from 500 to 13,500 $\mathrm{h}^{-1}$ ); 3) Pd loading (varied between $2 \mathrm{w} / \mathrm{w} \%$ Pd and $5 \mathrm{w} / \mathrm{w} \% \mathrm{Pd}$ ); 4) Sorbent make-up rate (varied between $3 \%, 1 \%$ ). The ranges were chosen in order to reasonably reflect, in the cases that are analyzed, the actual fluctuations that have been observed in past

\footnotetext{
${ }^{*}$ Corresponding author.
} 
experience in these important parameters that affect cost (e.g., the Pd cost has kept to within the $\$ 4$ to $12 \mathrm{k} / \mathrm{lb}$ range in recent years). In the case of $S V$, the high and low points of the range are extremes beyond which costs would either be unreasonable, or increase in cost benefit would be negligible. For a typical case (i.e., using mid-range values of the parameters, including SV of 8000 $\mathrm{h}^{-1}, \mathbf{2 \%}$ Pd loading, 3\% make-up rate, $\$ 9500 / \mathrm{lb}$ Pd cost), the increase in LCOE due to the Pd-polishing system is approximately $0.4 \%$ and the additional capital cost is $\sim \$ 10 / \mathrm{kW}$. As a comparison, the incremental capital cost of conventional $\mathrm{Hg}$ removal in an IGCC plant is $\sim \$ 4$ to $8 / \mathrm{kW}$, and the increase in the LCOE is less than $0.4 \%$. Results indicate that in the range of SVs from $3500 \mathrm{~h}^{-1}$ to $10,000 \mathrm{~h}^{-1}$, the Hg-polishing step is expected to function adequately and with increase of LCOE limited to about $1 \%-2 \%$. The use of a Pd sorbent-based polishing system to reduce trace $\mathrm{Hg}$ levels to the EPA MATS requirements for new IGCC power generation appears to be feasible and reasonably cost-effective.

\section{Keywords}

\section{Palladium, Sorbent, Mercury, Gasification, Integrated Gasification Combined Cycle, Cost}

\section{Introduction}

Gasification is used to convert a solid feedstock (coal, petcoke, biomass, etc.) into a gaseous form (synthesis gas [syngas]), which is primarily hydrogen and carbon monoxide (CO). At this point, potential pollutants can be captured and reduced to essentially any desired level and then converted to useful byproducts or disposed of safely. The clean syngas, consisting mainly of CO and hydrogen, can be fired in a gas-turbine/steam-turbine generator set to produce electricity. In addition to efficiently producing electric power, a wide range of highly valued transportation fuels and chemicals can be co-produced from the cleaned syngas, thereby providing the flexibility needed to capitalize on the changing economic market. As a result, gasification provides a flexible technology option for using domestically available resources while meeting any future environmental emission standards.

Gasification is an important strategy for increasing the utilization of abundant domestic US coal reserves. However, the increased use of coal gasification for energy generation, such as in integrated gasification combined cycle (IGCC) power plants, or for other purposes, requires responsible cleanup of contaminants resulting from the gasification process.

Recently, stringent regulations have been enacted for trace contaminant emissions from IGCC systems. Specifically, the US Environmental Protection Agency's (EPA) December 21, 2011, Mercury and Air Toxics Standards (MATS), the first national standards for mercury (Hg) pollution from power plants, require existing power plants to reduce $\mathrm{Hg}$ pollution by 90\%, reduce acidic gases (hydrogen chloride [HCl] and hydrogen fluoride [HF]) by $88 \%$, and substantially reduce other pollutants by 2015 [1]. Moreover, MATS requires new/in construction power plants to conform to even higher standards of upwards of $99.9 \%$. These have been officially reconsidered, with EPA issuing a notice of final action on reconsideration on March 28, 2013, and with EPA to submit it shortly for publication in the Federal Register (FR) [2]. EPA reported that implementation to meet proposed revised standards will be essentially the same as that which would have been chosen in complying with the original MATS rule [3]. The US Department of Energy (DOE) targets for trace contaminant removals are also stringent in order to avoid poisoning: 1) The catalysts essential for making liquids from fuel gas; 2) The electrodes in fuel cells; and 3) The selective catalytic reduction (SCR) catalysts employed in coal- or gas-burning power plants.

Capture of trace metal/toxic contaminants (Hg, arsenic [As], selenium [Se], cadmium [Cd], antimony [Sb], and phosphorus $[\mathrm{P}]$ ) found in coal-derived syngas is optimal at lower temperatures; many sorbents have been demonstrated for near-ambient temperature removal of $\mathrm{Hg}$ from natural gas and syngas and for removal of $\mathrm{Hg}$ from flue gas at temperatures up to $350^{\circ} \mathrm{F}$ [4]-[10]. However, these sorbents, typically activated carbon, have been reported to be unsatisfactory for $\mathrm{Hg}$ removal at temperatures exceeding $400^{\circ} \mathrm{F}$ [6] [11] [12]. In fact, few sorbents have been shown to remove Hg from high-temperature syngas because: 1) The physical adsorption of 
Hg on a sorbent typically decreases with increasing temperature; 2) Hg compounds formed on the surface of a sorbent can thermally decompose or desorb at high temperatures; and 3) Chemical promoters, such as sulfur or halogens, will desorb from the sorbent at elevated temperatures. In addition to these problems, carbon-based sorbents lack the desirable chemical resistance and regeneration capability properties for warm-gas cleanup (WGCU) [7].

Unfortunately, the limitations of current sorption technologies based on activated carbons are at odds with efforts to develop and implement high-temperature, or WGCU of syngas, which would boost the thermal efficiency of IGCC plants. WGCU would have the additional benefits of removing toxic contaminants from warm syngas nearer the gasifier exit, helping to eliminate the circulation of dirty water and treatment systems downstream in IGCC plants; reducing the footprint, cost, and complexity of the systems; and ensuring the disposition of trace metal pollutants so that they will not contaminate process equipment, poison raw materials, or foul catalysts or fuel cells [13]-[16]. Accordingly, the identification and development of a durable sorbent material capable of effectively and efficiently removing $\mathrm{Hg}$ and other trace metals at both elevated temperatures and pressures characteristic of actual process conditions have been a high priority.

Drawing on previous experience with sorbents in coal combustion flue gas, the National Energy Technology Laboratory (NETL) has selected potential high-temperature candidate sorbents, developed a process for testing the various candidate sorbents at bench-scale in simulated WGCU, and determined the capacities of the sorbents for capture of Hg, As, Se, and P. Palladium (Pd)-based sorbents are currently among the most promising candidates, as they have been found to effectively capture trace contaminants such as $\mathrm{Hg}$, As, Se, and P from syngas at elevated temperatures $\left(400^{\circ} \mathrm{F}\right.$ to $\left.700^{\circ} \mathrm{F}\right)$ [11]. The sorbents are described in US patent $7,033,419$, issued in April 2006. A license agreement between NETL and Johnson Matthey (JM) for further research, development, and commercialization of the sorbents for application in IGCC and in chemicals production from syngas was signed in March 2007. Collaboration between JM and NETL resulted in thorough characterization and benchscale tests of these Pd sorbents [4] [12] [17], including testing of the sorbent in slipstreams of dirty fuel gas that began in 2009. More recent tests of the technology at larger-scale have taken place at Southern Company's Power Systems Development Facility at the National Carbon Capture Center ${ }^{1}$. Initial results are highly promising, with more than $99 \%$ removal of $\mathrm{Hg}$, As, and Se from dirty fuel gas slipstreams at $550^{\circ} \mathrm{F}$ over long periods (several weeks).

\section{Purpose of Study}

This paper presents the results of a study to estimate the cost of a trace Hg-removal system using Pd sorbents in the context of an IGCC power plant. In cost and performance baselines for bituminous coal-fueled IGCC plants [18], raw syngas cleanup is accomplished through a sequence of quench and syngas scrubbing to remove particulates and solid matter, carbonyl hydrolysis, cooling and knockout of ammonia/sour water, conventional $\mathrm{Hg}$ removal using activated carbon adsorbent, and then a low-temperature acid gas removal system such as Selexol to remove the bulk of the sulfur in the syngas. In order to improve plant efficiency, there is interest in replacing the low-temperature gas cleanup with a high-temperature process that achieves comparable performance in gas cleanup without the penalty inherent in cooling the syngas to the low temperatures required in the Selexol process or other conventional sulfur-removal technologies. A novel WGCU technology has been developed by RTI International (RTI) that could have significant benefits over conventional syngas cleanup technologies. The RTI WGCU technology substantially modifies the low-temperature syngas cleanup approach by:

- Eliminating scrubbing and quench cooling.

- Replacing Selexol with the RTI high-temperature sulfur removal and recovery technology.

- Replacing conventional low-temperature Hg removal with a high-temperature Hg removal technology.

- Adding incidental chloride removal, SCR for control of the increased nitrogen oxide (NOX) emissions due to increased ammonia passing through the gas cleanup train, and other design features to accommodate process impacts.

The feasibility of a proprietary WGCU technology developed by RTI and impacts on the cost of electricity (COE) have been previously assessed [19]. The RTI Hg-removal technology could potentially lower the Hg content in the syngas to 5 parts per billion by weight $\left(\mathrm{ppb}_{\mathrm{w}}\right.$ ) [20]. However, an additional Hg-polishing step, equivalent to the removal of $\sim 60 \%$ of the Hg in the syngas exiting the WGCU operations, may be needed to attain the

\footnotetext{
${ }^{1}$ See http://www.nationalcarboncapturecenter.com/pdf/PSDF NCCC\%20Test\%20Run\%20R10\%20Summary\%20Report.pdf.
} 
new EPAMATS requirements for Hg (new IGCCs: $0.003 \mathrm{lb} \mathrm{Hg} / \mathrm{GWh}$ gross power generation).

A possible solution for the Hg-polishing step uses Pd sorbents in a fixed bed. NETL and JM have developed alumina-supported Pd sorbents that enable high-temperature $\left(>260^{\circ} \mathrm{C}\right) \mathrm{Hg}$ removal. Based on preliminary benchscale and syngas slipstream testing at Southern Company's pilot facility, this sorbent has the capability to perform the required Hg polishing [21]. Results also indicate that the Pd sorbents may be suitable for bulk Hg removal from syngas streams. The Hg-removal configuration analyzed in this study consists of the RTI WGCU technology for bulk Hg removal from the syngas, followed by Pd sorbent polishing to attain EPA MATS requirements.

The approach taken in this study has been to develop a simplified model of the Pd sorbent-based Hg-removal system, modify the IGCC baseline process including the RTI WGCU to integrate the Hg-removal system, and perform cost calculations to determine the incremental capital and operating costs impacting the COE.

\section{Process Description and Flow Diagrams}

In the context of an IGCC plant, the Hg-polishing system would be added directly following the bulk Hg removal in the WGCU step. The overall process diagram of the baseline IGCC plant, including the RTI WGCU and sulfur-recovery systems followed by the Hg-polishing system, is as depicted in Figure 1. This process configuration is essentially identical to the Case 4 process configuration from RTI/Nexant analyses, modified only by addition of the Hg-polishing system with its incidental power and steam demands on the overall plant process.

DOE/NETL has previously investigated the use of the JM Pd sorbents to remove Hg from coal gasification syngas. Detailed calculation procedures for determining extent of $\mathrm{Hg}$ removal using the Pd sorbents have been defined, accompanied by economic analysis to quantify costs of the Hg removal. The calculations assume a typical process arrangement for the sorbent-based Hg-removal system; this is depicted in Figure 2. The basic process configuration of the Pd sorbent system consists of four Pd sorbent fixed beds, two of them online and two in offline or regeneration mode. The online sorbent beds may be kept in operation cleaning syngas until Hg/trace breakthrough reaches the allowable limit. At this point, the syngas is rerouted to the other two regenerated beds. The exhausted beds are then regenerated by blowing hot carrier gas (nitrogen) through the beds, which strips most of the trace metals away. The carrier gas is cooled and passed through the disposable sorbent beds, removing the trace metals from the regenerator gas, which is then compressed, reheated, and cycled back. The regenerator gas is heated by steam of suitable quality to reach the required regenerator gas temperature of $400^{\circ} \mathrm{C}$ to $550^{\circ} \mathrm{C}$; this steam is withdrawn from the plant steam cycle.

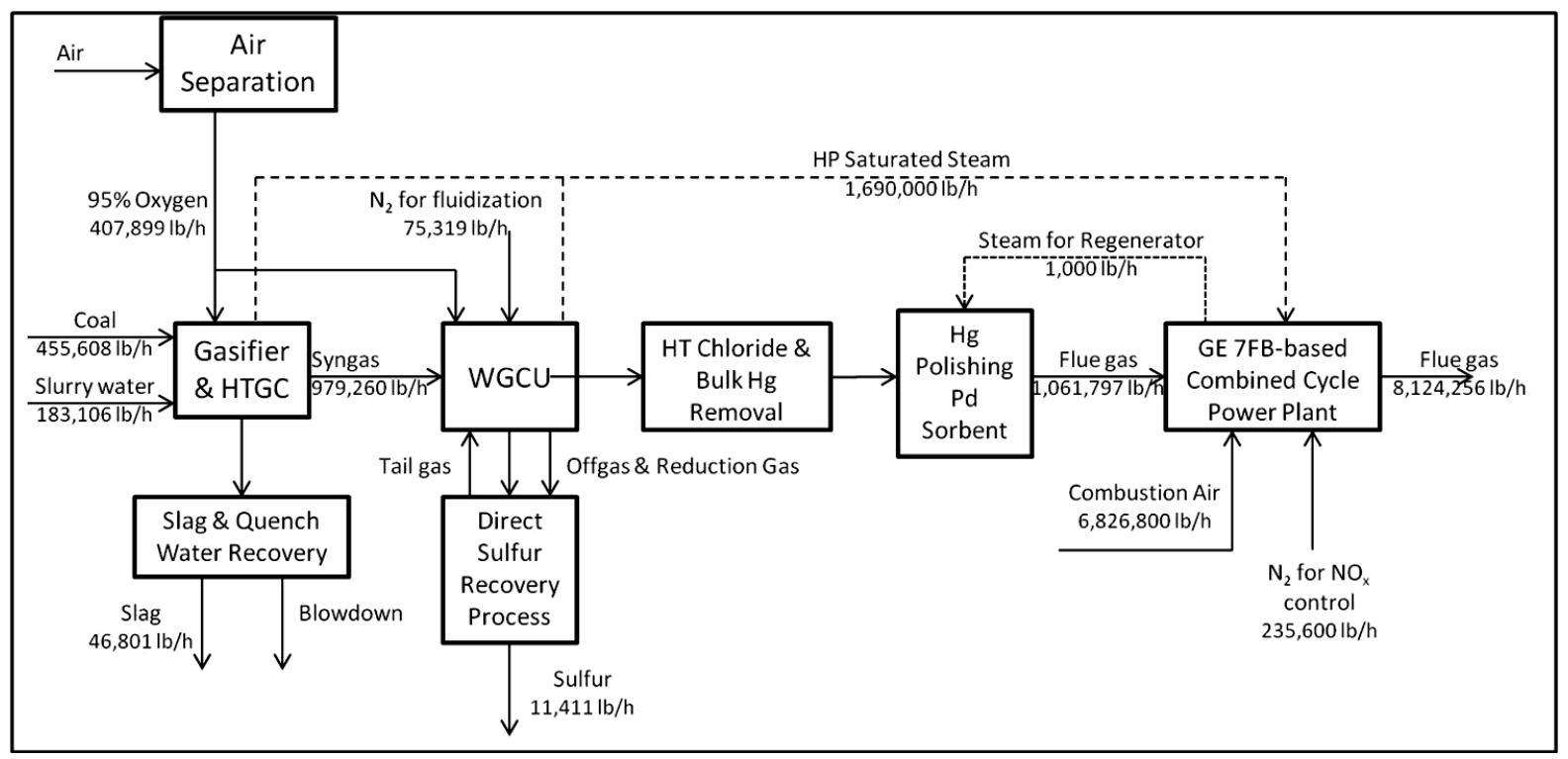

Figure 1. Block diagram of IGCC plant with RTI warm-gas cleanup and addition of Pd sorbent-based polishing unit. 


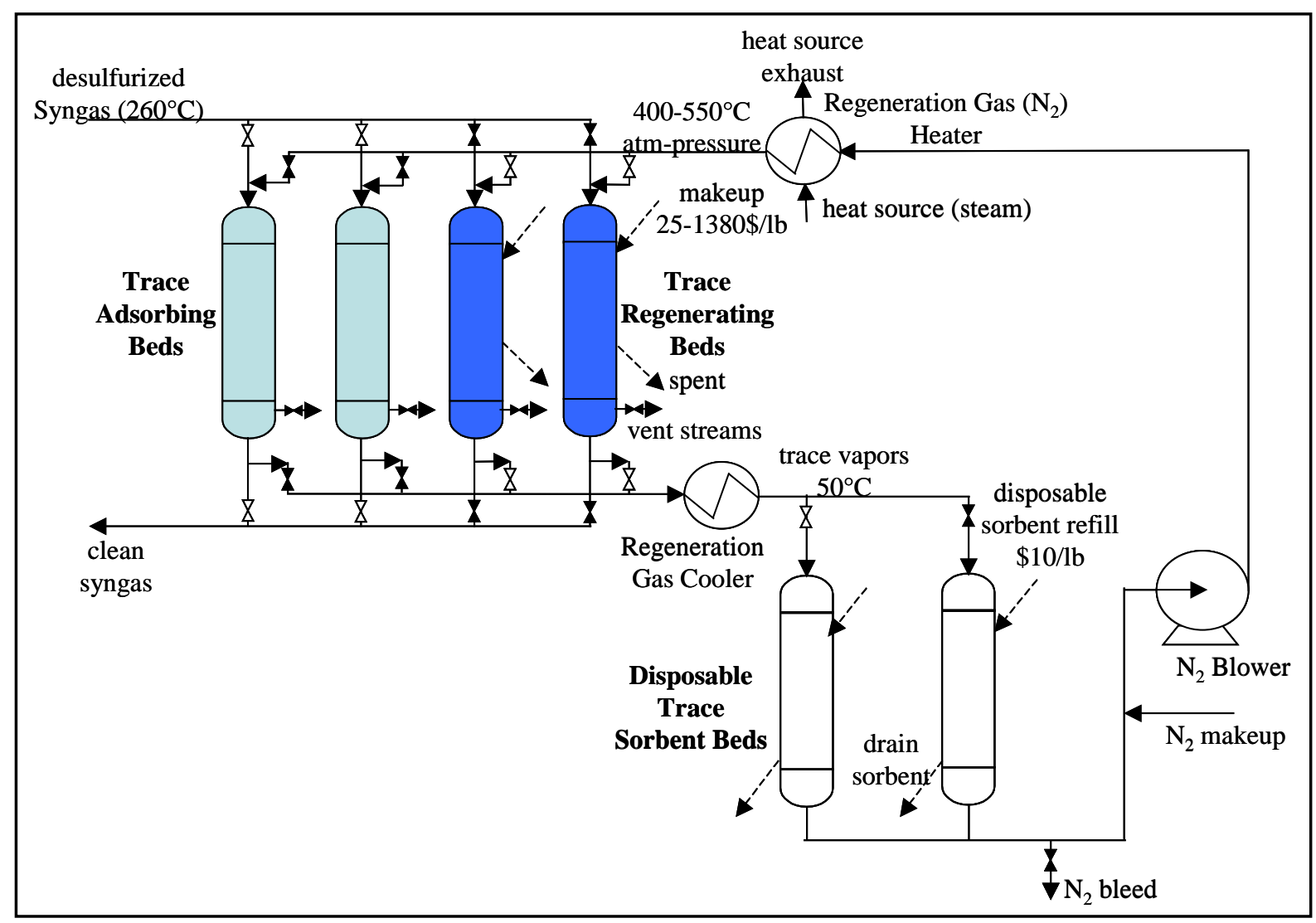

Figure 2. Pd sorbent unit process flow diagram.

As expected, there are considerable differences in gas flow rates, Hg concentrations and key operating conditions (pressure) between the current application (Hg polishing using Pd sorbents), and previous analysis that considered bulk-removal of Hg using the RTI WGCU technology. In this study, a new set of assumptions about parameters governing the performance of the Pd sorbent unit in the IGCC plant context was developed for the concept of Hg polishing to low levels. In this context, analysis of how the levelized cost of electricity (LCOE) is affected by the Pd cost, Pd loading in the sorbent, gas hourly space velocity (SV), and sorbent make-up rates has been performed. Given the substantial changes in equipment sizes, rates, and fluctuations in Pd value in recent years, equipment and other capital costs (adsorber pressure vessels constitute an important capital cost element in addition to the sorbent cost) were also updated. The impact of steam consumption, electric loads, and pressure drop due to the Pd sorbent system on power plant performance was quantitatively accounted.

\section{Design Rationale for Case Studies}

\subsection{Description of Case Studies}

The most significant parameters affecting the cost of Hg capture are the cost of the Pd sorbent, the amount of sorbent in the bed (inversely proportional to the SV), sorbent make-up rate, and the quantity of Pd in the sorbent. Published RTI/Nexant analysis was used as a basis for LCOE calculations ${ }^{2}$. Various cases were devised, summarized in Table 1, to examine the effects of these parameters.

The base case was designed having mid-range values of the parameters, and which is expected to represent a reasonable, typical case. This case assumes $2 \% \mathrm{w} / \mathrm{w} \mathrm{Pd} /$ alumina sorbent, with an SV of $8000 \mathrm{~h}^{-1}$, Pd cost of $\$ 9500 / \mathrm{lb}\left(\sim 651 /\right.$ troy ounce [trz]), and a sorbent make-up rate of 3\%. SVs of 500 to $13,500 \mathrm{~h}^{-1}$ were chosen because preliminary studies revealed that the adsorber volume and cost would increase significantly below $500 \mathrm{~h}^{-1}$. Little change in adsorber volume was observed with SVs in excess of 15,000 $\mathrm{h}^{-1}$. Palladium sorbent costs were approximated to be those of the pure metal. Pure Pd costs spanning a time period of three-plus years (2010

${ }^{2}$ Case 4, 641 MW net power, 6.47 cents/kWh LCOE with RTI warm-gas cleanup to 5 ppbw Hg. 
Table 1. Summary of various cases.

\begin{tabular}{lcccc}
\hline & Pd Sorbent Loading, w/w\% & Pd Price, $\$ \mathbf{l b}$ & Space Velocity, $\mathbf{~}^{\mathbf{- 1}}$ & Make-Up Rate, wt\% Bed \\
\hline Case 1a & 2 & 9500 & 500 to 13,500 & 3 \\
Case 1b & 2 & 4000 to 12,000 & 8000 & 3 \\
Case 2a & 2 & 9500 & 500 to 13,500 & 1 \\
Case 2b & 2 & 4000 to 12,000 & 8000 & 3 \\
Case 3a & 5 & 9500 & 500 to 13,500 & 3 \\
Case 3b & 5 & 4000 to 12,000 & 8000 & 1 \\
Case 4a & 5 & 9500 & 500 to 13,500 & 1 \\
Case 4b & 5 & 4000 to 12,000 & 8000 & 3 \\
\hline
\end{tabular}

to 2013) were used to obtain the range of variation for Pd cost. Recent pilot plant tests at Southern Company used a $2 \mathrm{w} / \mathrm{w} \%$ Pd sorbent with an SV of $1704 \mathrm{~h}^{-1}$; accordingly, 2\% and 5\% Pd sorbents were used. Bed makeup rates were varied from 3 to $1 \%$ of the bed weight. Previous NETL experience indicates that $40 \% \mathrm{Hg}$ content (wt $\mathrm{Hg} / \mathrm{wt} \mathrm{Pd}$ ) at $40 \%$ breakthrough is a reasonable assumption. The adsorber beds were sized to be 10 feet in diameter for reasonable superficial gas velocities and pressure drops lower than $4 \%$.

\subsection{Extent of Hg Capture Needed to Satisfy EPA MATS}

The RTI WGCU process was assumed to remove $\mathrm{Hg}$ to $5 \mathrm{ppb}_{\mathrm{w}}$ in the clean syngas to the turbine. The EPA MATS requirement for $\mathrm{Hg}$ emissions is $0.003 \mathrm{lb} / \mathrm{GWh}$ gross power output $\left(2 \mathrm{ppb}_{\mathrm{w}}\right)$. For the Nexant RTI Case 4 chosen as the power plant for this study, the gross power output is 766 MW. Accordingly, the Hg emissions without a polishing step would be $6.93 \times 10^{-3} \mathrm{lb} / \mathrm{GWh}$. Therefore, the extent of $\mathrm{Hg}$ removal needed to meet EPA MATS is $\sim 57 \%$. This implies that the Hg breakthrough in the beds would be approximately $40 \%$ ( 60\% capture).

\section{Calculation Methodology}

A model of the Pd sorbent process was developed to account for the new operating conditions and parameters. It is restricted to cases with only $\mathrm{Hg}$ adsorption (i.e., no co-adsorption of As, Se, and P is considered). The capital and operating \& maintenance ( $\mathrm{O} \& \mathrm{M}$ ) costs of capturing $\mathrm{Hg}$ are estimated using bed residence time, Pd price, Pd sorbent weight\%, Hg content at breakthrough, and make-up rate as primary input parameters in the spreadsheet. Process simulations for the IGCC plant indicated that the exhaust gas composition and conditions following the combustion turbine are independent of the extent of water-gas shift (WGS) reaction occurring in the Pd sorbent beds. Because plant performance and cost calculations would not be affected, $0 \%$ WGS in the adsorber is assumed.

\subsection{Cost of Sorbent}

The cost of the Pd sorbent-based Hg-removal unit is dominated by the cost of the sorbent itself, because it incorporates a significant quantity of Pd metal with recent spot prices as high as $\sim 9900$ (September 2014). However, sorbent fabrication and ongoing refining costs to maintain the sorbent in working order also contribute to capital and O \& M costs, respectively, associated with this unit. The amount of Pd initially required for the four sorbent vessels is used to calculate the sorbent cost. This estimate includes $\sim 20 \%$ storage/excess sorbent capacity stored onsite.

\subsection{Effects of Gas Residence Time, Superficial Velocity, and Pressure Drop}

The volume of gas contacted per unit mass of adsorbent, SV/ $\mathrm{X}_{\mathrm{Pd}}$, where $\mathrm{SV}$ is the space velocity and $\mathrm{X}_{\mathrm{Pd}}$ is the weight percentage of Pd in the sorbent, is a primary parameter affecting the cost of Hg capture. Given a specific value for $\mathrm{X}_{\mathrm{Pd}}$, and assuming no mass transfer limitations, higher SVs lead to lower initial sorbent costs. Mini-

\footnotetext{
${ }^{3} \mathrm{Hg}$ content in bed at $40 \%$ breakthrough, is assumed to be $40 \%$ wt $\mathrm{Hg} / \mathrm{wt} \mathrm{Pd}$ in all cases.
} 
mizing the amount of sorbent requires higher gas velocities through the material and/or shorter gas residence times (higher SVs). In applications where a large volume of syngas volumetric flow with low inlet Hg concentrations exists, the required amount of sorbent to provide adequate Hg capture capacity might be relatively low. However, this corresponds to very short gas residence times in the sorbent bed ( $<<1$ second) in which mass transfer constraints might not allow sufficient capture of Hg. Increasing residence time by decreasing the cross-sectional area of the sorbent beds increases pressure drop in the sorbent beds and the associated energy penalty. Acceptable pressure drop has been assumed to be $4 \%$ of the inlet gas pressure. Testing of the Pd sorbent for $\mathrm{Hg}$ capture in Southern Company tests provides some guidance on required operating conditions and parameters, with SVs of 1500 to $3700 \mathrm{~h}^{-1}$, and pressures 150 to 200 pounds per square inch gauge (psig) [21].

Even a small pressure drop attributable to an Hg-polishing sorbent unit could have a negative impact on the overall efficiency of a gas turbine cycle. In the recent baseline IGCC plant Case 1 (as described in the NETL Bituminous Baseline report) [22], the GE advanced F class turbine is noted to have a requirement for gas feed at 450 pounds per square inch absolute (psia). In this case, syngas was expanded to 460 psia to generate some power before the gas turbine. In earlier baseline IGCC plant cases [18] (which Nexant adopted as a baseline for their original analysis), advanced turbines of that time had somewhat lower pressure ratios, which in turn corresponded to lower syngas inlet pressures. Accordingly, the RTI WGCU Case 4 plant cycle analysis had the syngas pressure entering the turbine at 414.7 psia, which was likely just sufficient for turbine operability at that time. In other words, there was no syngas expander present because the gasifier operated at a significantly lower pressure, and after gas cleanup the syngas was already depressed to a suitable gas turbine inlet pressure (414.7 psia). A recent discussion with the GE turbine manufacturer ${ }^{4}$ confirmed that significant fuel gas pressure drop occurs in the turbine valving, piping, controllers, and injection nozzles; accordingly, the pressure specified for the gas turbines (450 psia in the NETL bituminous baseline report, 414.7 psia in the Nexant 2007 study) must be maintained. Consequently, in the present analysis, a penalty is taken in the form of a compression duty for recompressing the syngas exiting the adsorbers to the original pressure ( $414.7 \mathrm{psia})$ to compensate for any pressure drop due to the Hg-polishing unit. If the Nexant study were updated in accordance with latest NETL baseline, reflecting the availability of more advanced turbines and higher gasifier pressure along with a syngas expander upstream from the turbine, then pressure drop associated with addition of the Hg-polishing unit would be accounted for by a lower inlet pressure to the expansion turbine (which would result in lower attained turbine output).

\section{Results and Discussion}

\subsection{Effect of Hg Polishing System on Plant Power}

The Hg-removal system affects plant power output in three main respects: 1) The pressure drop of the syngas through the sorbent vessels for which an energy penalty is taken; 2) The power to operate the regeneration gas circulating blower; and 3) The steam to heat the regeneration gas, which is taken from the main plant steam cycle, causing a decrease in steam turbine output. In order to calculate these accurately, a process model of the IGCC plant was developed in a process simulator, in which syngas flows, steam flows, the gas turbine, steam turbine, and Hg-sorbent unit including the regenerator were modeled to a sufficient extent to determine impacts of the Hg-polishing system on plant net output. The results of the plant simulation in terms of key impacts of the Hg-removal system on plant power are shown in Table 2.

The energy penalty from the pressure drop through the $\mathrm{Hg}$ vessels is by far the most significant impact. It increases into the several MW range for lower SV values. The $1000 \mathrm{lb} / \mathrm{hr}$ of $538^{\circ} \mathrm{C}$ steam withdrawn from the steam cycle causes a loss of approximately $100 \mathrm{~kW}$ in the gross output of the steam turbine; it is relatively insignificant because the total steam flow in the cycle is more than $1,000,000 \mathrm{lb} / \mathrm{hr}$. The power to operate the nitrogen $\left(\mathrm{N}_{2}\right)$ blower, which provides $2000 \mathrm{lb} / \mathrm{hr}$ of $\mathrm{N}_{2}$ at $525^{\circ} \mathrm{C}$ for the regeneration cycles, is negligible at about $20 \mathrm{~kW}$.

\subsection{Analysis of Levelized Cost of Electricity}

The increase in the LCOE of the IGCC plant and the incremental capital cost $(\$ / \mathrm{kW})$ were estimated for all cases, and are shown in Figure 3 and Figure 4. In general, higher values of gas hourly SV and lower Pd costs and loadings lead to lower increases in the LCOE.

\footnotetext{
${ }^{4}$ Conversation with Jeff Goldmeer (jeffrey.goldmeer@ge.com) of GE Power early February 2012.
} 
Table 2. Effect of pressure drop caused by Hg-polishing system on net power generated.

\begin{tabular}{|c|c|c|c|c|c|}
\hline & Baseline Plant & $\begin{array}{c}\text { Pd Bed, } \\
S V=13,500 h^{-1}\end{array}$ & $\begin{array}{c}\text { Pd Bed, } \\
\mathrm{SV}=4500 \mathrm{~h}^{-1}\end{array}$ & $\begin{array}{c}\text { Pd Bed, } \\
\mathrm{SV}=1500 \mathrm{~h}^{-1}\end{array}$ & $\begin{array}{c}\text { Pd Bed, } \\
\mathrm{SV}=500 \mathrm{~h}^{-1}\end{array}$ \\
\hline $\begin{array}{c}\text { Pressure Drop } \\
\text { Penalty, MW }\end{array}$ & None & 0.21 & 0.63 & 1.94 & 6.28 \\
\hline $\begin{array}{c}\mathrm{N}_{2} \text { Blower } \\
\text { Penalty, MW }\end{array}$ & None & & & & 0.02 \\
\hline $\begin{array}{l}\text { Steam Turbine } \\
\text { Output, MW }\end{array}$ & 316.7 & & & & 316.6 \\
\hline Net Plant Power, MW & 641.0 & 640.8 & 640.5 & 639.8 & 637.3 \\
\hline
\end{tabular}

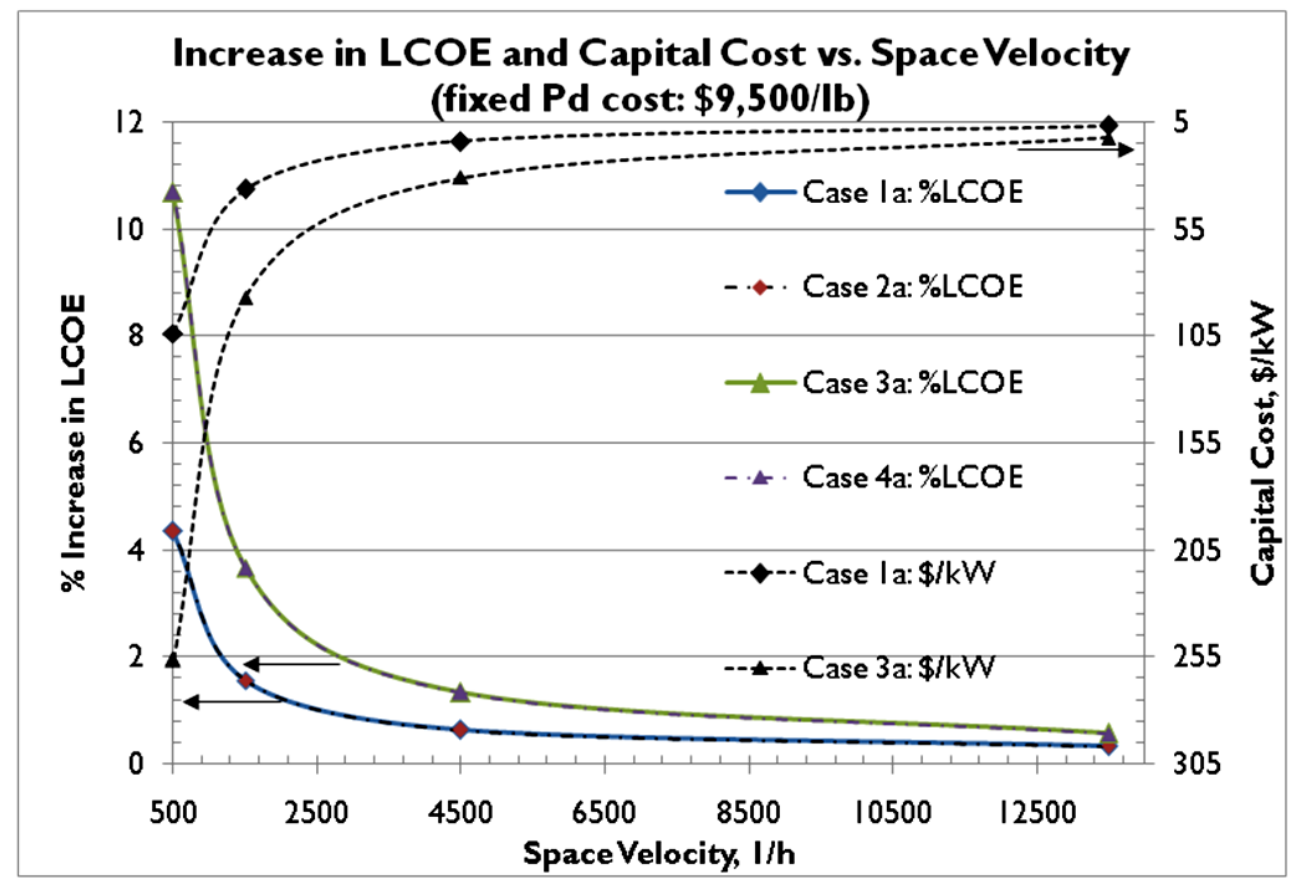

Figure 3. Effect of varying space velocity on increase in LCOE and capital cost for $2 \%$ wt Pd sorbent (Case 1a, Case 2a) and 5\% wt Pd sorbent (Case 3a, Case 4a) and make-up rates of 3\% (Case 1a, Case 3a) and 1\% (Case 2a, Case 4a). The palladium cost was fixed at $\$ 9500 / \mathrm{lb}$ ( $\$ 651 / \mathrm{trz})$.

As the SV is varied from 500 to $13,500 \mathrm{~h}^{-1}$, keeping the cost of Pd constant at $\$ 651 /$ trz with $2 \%$ wt Pd sorbent and 3\% make-up rate, the percentage increase in LCOE is $\sim 0.3 \%$ to $4.3 \%$ (Figure 3).The incremental capital cost of the system (including the cost of the sorbent and the cost of the adsorber vessels) increases from $\sim \$ 7 / \mathrm{kW}$ at $\mathrm{SV}=13,500 \mathrm{~h}^{-1}$ to $\$ 104 / \mathrm{kW}$ at $\mathrm{SV}=500 \mathrm{~h}^{-1}$. Similarly, with $5 \mathrm{wt} \% \mathrm{Pd}$ sorbent and $3 \%$ make-up rate, the increase in LCOE is $0.6 \%\left(\mathrm{SV}=13,500 \mathrm{~h}^{-1}\right)$ to $10.7 \%\left(\mathrm{SV}=500 \mathrm{~h}^{-1}\right)$, and the incremental capital cost increased from $\sim \$ 13 / \mathrm{kW}\left(\mathrm{SV}=13,500 \mathrm{~h}^{-1}\right)$ to $\$ 257 / \mathrm{kW}\left(\mathrm{SV}=500 \mathrm{~h}^{-1}\right)$. Very little change in the percentage of LCOE increase with the make-up rate for a sorbent utilization value of $40 \%$ (wt Hg/wt Pd) in the adsorbers is observed. From Figure 3 it is clear that the optimal values for the gas hourly $\mathrm{SV}$ would be $\geq 3500 \mathrm{~h}^{-1}$.

Figure 4 represents the effect of the cost of Pd on LCOE and the capital cost with 2 wt\% and 5 wt\% Pd sorbents and $3 \%$ and $1 \%$ sorbent make-up rates, with a fixed SV of $8000 \mathrm{~h}^{-1}$. As the cost of Pd is increased from $\$ 274 /$ trz $(\sim 4000 / \mathrm{lb})$ to $\$ 823 /$ trz $(\sim 12,000 / \mathrm{lb})$, the percentage increase in LCOE increases from $0.3 \%$ to $0.5 \%$ for 2 wt $\%$ Pd sorbent with 3\% make-up rate, and from $0.5 \%$ to $1 \%$ for the 5 wt\% Pd sorbent with 3\% make-up rate, respectively. The incremental capital cost of the adsorbers (Pd sorbent, vessel cost) is increased from $\$ 6$ to $\$ 11 / \mathrm{kW}$ for the $2 \%$ Pd sorbent, and from $\$ 10$ to $\$ 23 / \mathrm{kW}$ for the $5 \mathrm{wt} \%$ Pd sorbent, respectively. Decreasing the sorbent make-up rate decreases the increase in LCOE, but to an insignificant extent. Changes in sorbent makeup rate do not affect the incremental capital cost in all cases. 


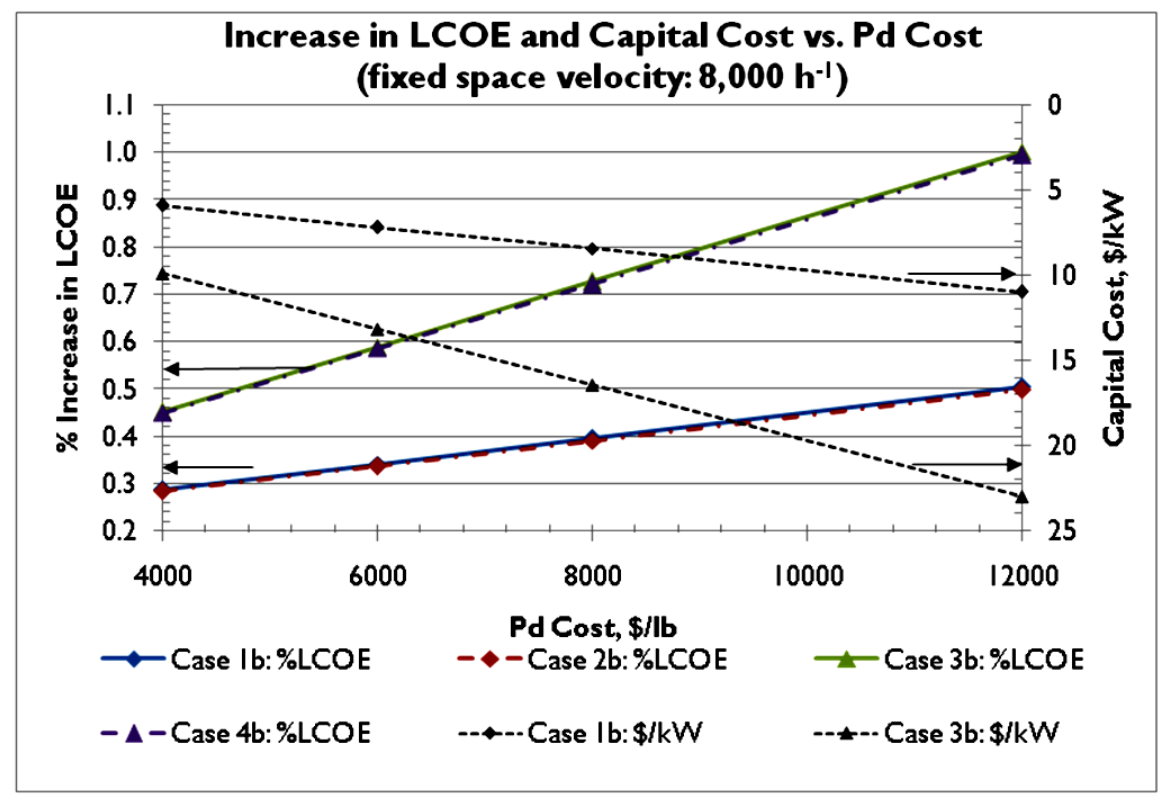

Figure 4. Effects of Pd cost on increase in LCOE and capital cost for $2 \%$ wt Pd sorbent (Case 1b, Case 2b) and 5\% wt Pd sorbent (Case 3b, Case 4b) and make-up rates of 3\% (Case $1 \mathrm{~b}$, Case $3 \mathrm{~b}$ ) and $1 \%$ (Case $2 \mathrm{~b}$, Case $4 \mathrm{~b}$ ). The gas hourly space velocity was fixed at $8000 \mathrm{~h}^{-1}$.

For the base case, the performance of the Hg-polishing sorbent system $(\sim 0.4 \%$ increase in LCOE, $\sim \$ 10 / \mathrm{kW}$ incremental capital cost for the base case SV $=8000 \mathrm{~h}^{-1}$, \$9500/lb Pd, $2 \mathrm{w} / \mathrm{w} \%$ Pd sorbent, $3 \%$ make-up rate) is comparable to that of the carbon-based, low-temperature Hg adsorbers $(<0.4 \% \text { increased LCOE, } \$ 4 \text { to } \$ 8 / \mathrm{kW})^{5}$. Therefore, the Hg-polishing system holds significant promise to lower the cost of Hg capture from warm syngas streams.

\section{Summary}

In this analysis, a number of assumptions, based on experimental results and other studies, were made about Pd sorbent operating characteristics and constraints. To decrease the uncertainty associated with those assumptions, parameters such as Pd cost, SV, sorbent composition, and sorbent make-up rate were varied over possible ranges while observing the effects on performance and costs.

Preliminary results from this study indicate that a Pd sorbent-based polishing system in an IGCC plant with WGCU could be used to reduce trace Hg levels to the new EPA MATS requirements for IGCC power generation in a cost-effective manner. For gas hourly SVs greater than $3500 \mathrm{~h}^{-1}$, COE is elevated less than $2 \%$ by addition of the Hg-polishing step. For SVs greater than $10,000 \mathrm{~h}^{-1}$, the COE increase continues to improve marginally, but it is likely that $\mathrm{Hg}$ mass-transfer limitations may limit the performance of the Pd sorbent system at these higher SVs (high gas velocities and low gas residence times) in the sorbent beds. Accordingly, for a range of SVs from 3500 to $10,000 \mathrm{~h}^{-1}$, the Hg-polishing step is expected to function adequately and with an increase of LCOE limited to approximately $1 \%$ to $2 \%$. As a comparison, the incremental capital cost of conventional (95\%) Hg removal in an IGCC plant is $\sim \$ 4$ to $\$ 8 / \mathrm{kW}$, with less than $0.4 \%$ increase in the LCOE [22].

Cost of the Pd sorbent-based polishing system is strongly affected by the cost of the sorbent, which in turn depends primarily upon the cost of Pd. Large and unpredictable fluctuations in the cost of Pd will necessarily have a corresponding impact on the capital cost of a system, as illustrated by case studies in which the price of Pd was varied. For higher SVs, less sorbent and less Pd are required, though as previously discussed there will be practicable limits on how far this can be taken.

Further testing of the Pd sorbent at actual conditions and trace Hg levels in the IGCC Hg-polishing scenario would be highly desirable to confirm the assumptions and results of this study. In addition to the use of Pd-based sorbent for polishing (i.e., reducing $\mathrm{Hg}$ levels from $5 \mathrm{ppb}_{\mathrm{w}}$ to $2 \mathrm{ppb}_{\mathrm{w}}$ ), the sorbent could also be used for bulk $\mathrm{Hg}$ 
removal from syngas. Finally, the present analysis was restricted to cases assuming only Hg adsorption, so the effects of additional adsorption of As, Se, and P were not explored. Nevertheless, these may have significant impact on $\mathrm{Hg}$ adsorption capacity/characteristics, and so future work should extend to consider the overall behavior of Pd sorbents for simultaneous removal of $\mathrm{Hg}$ and these additional pollutant species.

\section{Disclaimer}

This article discusses research and development sponsored by an agency of the United States Government. Neither the United States Government nor any agency thereof, nor any of their employees, makes any warranty, express or implied, or assumes any legal liability or responsibility for the accuracy, completeness, or usefulness of any information, apparatus, product, or process disclosed, or represents that its use would not infringe privately owned rights. Reference herein to any specific commercial product, process, or service by trade name, trademark, manufacturer, or otherwise does not necessarily constitute or imply its endorsement, recommendation, or favoring by the United States Government or any agency thereof. The views and opinions of authors expressed herein do not necessarily state or reflect those of the United States Government or any agency thereof.

\section{Acknowledgements}

The authors thank Henry Pennline (NETL) and the staff at Johnson Matthey for their excellent guidance, contributions, and cooperation.

\section{References}

[1] Environmental Protection Agency (2012) National Archives and Records Administration: Federal Register. 9303.

[2] Environmental Protection Agency, 40 CFR Parts 60 and 63[EPA-HQ-OAR-2009-0234; EPA-HQ-OAR-2011-0044, FRL9148-5]RIN 2060-AP52 (2014) National Emission Standards for Hazardous Air Pollutants from Coal- and Oil-Fired Electric Utility Steam Generating Units and Standards of Performance for Fossil-Fuel-Fired Electric Utility, IndustrialCommercial-Institutional, and Small Industrial-Commercial-Institutional Steam Generating Units. http://www.epa.gov/airquality/powerplanttoxics/pdfs/proposal.pdf

[3] Environmental Protection Agency (2012) In 40 CFR Parts 60 and 63; Federal Register. Environmental Protection Agency, Washington DC, 71323.

[4] Poulston, S., Granite, E.J., Pennline, H.W., Myers, C.R., Stanko, D.P., Hamilton, H., Rowsell, L., Smith, A.W.J., Ilkenhans, T. and Chu, W. (2007) Metal Sorbents for High Temperature Mercury Capture from Fuel Gas. Fuel, 86, 2201-2203. http://dx.doi.org/10.1016/j.fuel.2007.05.015

[5] Wendt, J.O.L. and Lee, S.J. (2010) High-Temperature Sorbents for Hg, Cd, Pb, and Other Trace Metals: Mechanisms and Applications. Fuel, 89, 894-903. http://dx.doi.org/10.1016/j.fuel.2009.01.028

[6] Granite, E.J., Pennline, H.W. and Hargis, R.A. (2000) Novel Sorbents for Mercury Removal from Flue Gas. Industrial \& Engineering Chemistry Research, 39, 1020-1029. http://dx.doi.org/10.1021/ie990758v

[7] Reed, G.P., Ergüdenler, A., Grace, J.R., Watkinson, A.P., Herod, A.A., Dugwell, D. and Kandiyoti, R. (2001) Control of Gasifier Mercury Emissions in a Hot Gas Filter: The Effect of Temperature. Fuel, 80, 623-634. http://dx.doi.org/10.1016/S0016-2361(00)00148-4

[8] Wu, S.J., Uddin, Md.A. and Sasaoka, E. (2006) Characteristics of the Removal of Mercury Vapor in Coal Derived Fuel Gas over Iron Oxide Sorbents. Fuel, 85, 213-218. http://dx.doi.org/10.1016/j.fuel.2005.01.020

[9] Zhang, H., Zhao, J., Fang, Y., Huang, J. and Want, Y. (2012) Catalytic Oxidation and Stabilized Adsorption of Elemental Mercury from Coal-Derived Fuel Gas. Energy \& Fuels, 26, 1629-1637. http://dx.doi.org/10.1021/ef201453d

[10] McNamara, J.D. and Wagner, N.J. (1996) Process Effects on Activated Carbon Performance and Analytical Methods Used for Low Level Mercury Removal in Natural Gas Applications. Gas Separation and Purification, 10, 137-140. http://dx.doi.org/10.1016/0950-4214(96)00005-9

[11] Granite, E.J., Myers, C.R., King, W.P., Stanko, D.C. and Pennline, H.W. (2006) Sorbents for Mercury Capture from Fuel Gas with Application to Gasification Systems. Industrial \& Engineering Chemistry Research, 45, 4844-4848. http://dx.doi.org/10.1021/ie060456a

[12] Poulston, S., Granite, E.J., Pennline, H.W., Hamilton, H. and Smith, A.W.J. (2011) Palladium Based Sorbents for High Temperature Arsine Removal from Fuel Gas. Fuel, 90, 3118-3121. http://dx.doi.org/10.1016/j.fuel.2011.05.012

[13] Quinn, R., Mebrahtu, T., Dahl, T.A., Lucrezi, F.A. and Toseland, B.A. (2004) The Role of Arsine in the Deactivation of Methanol Synthesis Catalysts. Applied Catalysis A: General, 264, 103-109. 
http://dx.doi.org/10.1016/j.apcata.2003.12.034

[14] Coade, R. and Coldham, D. (2006) The Interaction of Mercury and Aluminium in Heat Exchangers in a Natural Gas Plants. International Journal of Pressure Vessels and Piping, 83, 336-342. http://dx.doi.org/10.1016/j.ijpvp.2006.02.022

[15] Nichols, H. and Rostoker, W. (1961) On the Mechanism of Crack Initiation in Embrittlement by Liquid Metals. Acta Metallurgica, 9, 504-509. http://dx.doi.org/10.1016/0001-6160(61)90145-6

[16] Cayan, F.N., Zhi, M., Pakalapati, S.R., Celik, I., Wu, N. and Gemmen, R. (2008) Effects of Coal Syngas Impurities on Anodes of Solid Oxide Fuel Cells. Journal of Power Sources, 185, 595-602. http://dx.doi.org/10.1016/j.jpowsour.2008.06.058

[17] Baltrus, J.P., Granite, E.J., Pennline, H.W., Stanko, D., Hamilton, H., Rowsell, L., Poulston, S., Smith, A. and Chu, W. (2010) Surface Characterization of Palladium-Alumina Sorbents for High-Temperature Capture of Mercury and Arsenic from Fuel Gas. Fuel, 89, 1323-1325. http://dx.doi.org/10.1016/j.fuel.2009.09.030

[18] Cost and Performance Baseline for Fossil Energy Plants. Vol. 1, DOE/NETL-2007/1281, May 2007.

[19] Preliminary Feasibility Analysis of RTI Warm Gas Cleanup (WGCU) Technology, Nexant, June 2007. http://www.canadiancleanpowercoalition.com/files/7112/7723/6492/CCS8\%20-\%20090520_Nexant_RTI_Rp_Public. pdf

[20] NETL Factsheet, RECOVERY ACT: Scale-Up of High-Temperature Syngas Cleanup Technology. http://www.netl.doe.gov/publications/factsheets/project/FE0000489.pdf

[21] Granite, E.J., Pennline, H.W., Rupp, E.C., Baltrus, J.P., Stanko, D.C., Howard, B.H., Guenther, C. and Tennant, J.-NETL; Hamilton, H., Poulston, S., Rowsell, L., Chu, W. and Smith, A.-Johnson Matthey; Wu, T., Datta, S., Lambrecht, B. and Wheeldon, J.-Southern Company (2011) Palladium Sorbents for High Temperature Capture of Mercury, Arsenic, Selenium and Phosphorus from Fuel Gas. West Virginia University Seminar, Morgantown, 28 October 2011.

[22] Cost and Performance Baseline for Fossil Energy Plants, Vol. 1, Bituminous Coal and Natural Gas to Electricity. DOE/NETL-2010/1397, September 2013. http://www.netl.doe.gov/File\%20Library/Research/Energy\%20Analysis/OE/BitBase_FinRep_Rev2a-3_20130919_1.p df 


\section{Abbreviation}

As: Arsenic

Cd: Cadmium

COE: Cost of Electricity

DOE: US Department of Energy

EPA: US Environmental Protection Agency

FR: Federal Register

HCl: Hydrogen Chloride

HF: Hydrogen Fluoride

Hg: Mercury

IGCC: Integrated Gasification Combined Cycle

JM: Johnson Matthey

LCOE: Levelized Cost of Electricity

MATS: Mercury and Air Toxics Standards

$\mathrm{N}_{2}$ : Nitrogen

NETL: National Energy Technology Laboratory

$\mathrm{NO}_{\mathrm{X}}$ : Nitrogen Oxides

O \& M: Operation and Maintenance

ORD: Office of Research and Development

P: Phosphorus

Pd: Palladium

$\mathrm{ppb}_{\mathrm{w}}$ : Parts per Billion by Weight

psia: Pounds per Square Inch Absolute

psig: Pounds per Square Inch Gauge

RTI: RTI International

Sb: Antimony

SCR: Selective Catalytic Reduction

Se: Selenium

SV: Space Velocity

Syngas: Synthesis Gas

Trz: Troy Ounce

WGCU: Warm-Gas Cleanup

WGS: Water-Gas Shift 
Scientific Research Publishing (SCIRP) is one of the largest Open Access journal publishers. It is currently publishing more than 200 open access, online, peer-reviewed journals covering a wide range of academic disciplines. SCIRP serves the worldwide academic communities and contributes to the progress and application of science with its publication.

Other selected journals from SCIRP are listed as below. Submit your manuscript to us via either submit@scirp.org or Online Submission Portal.
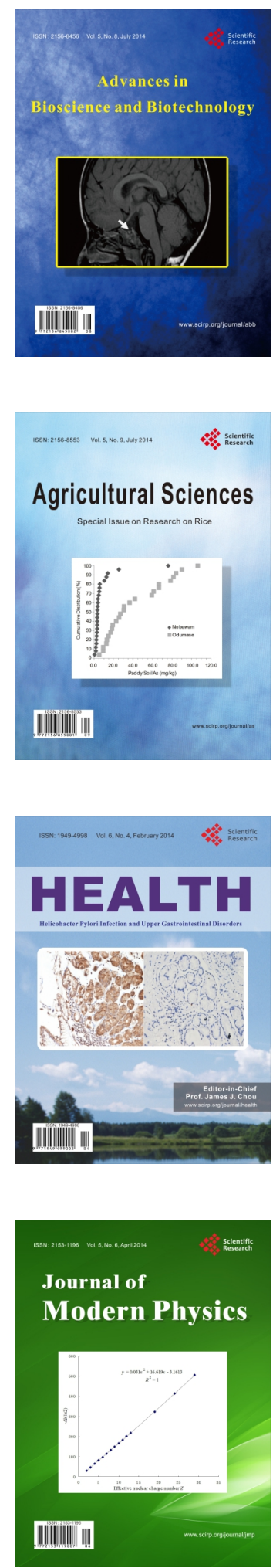
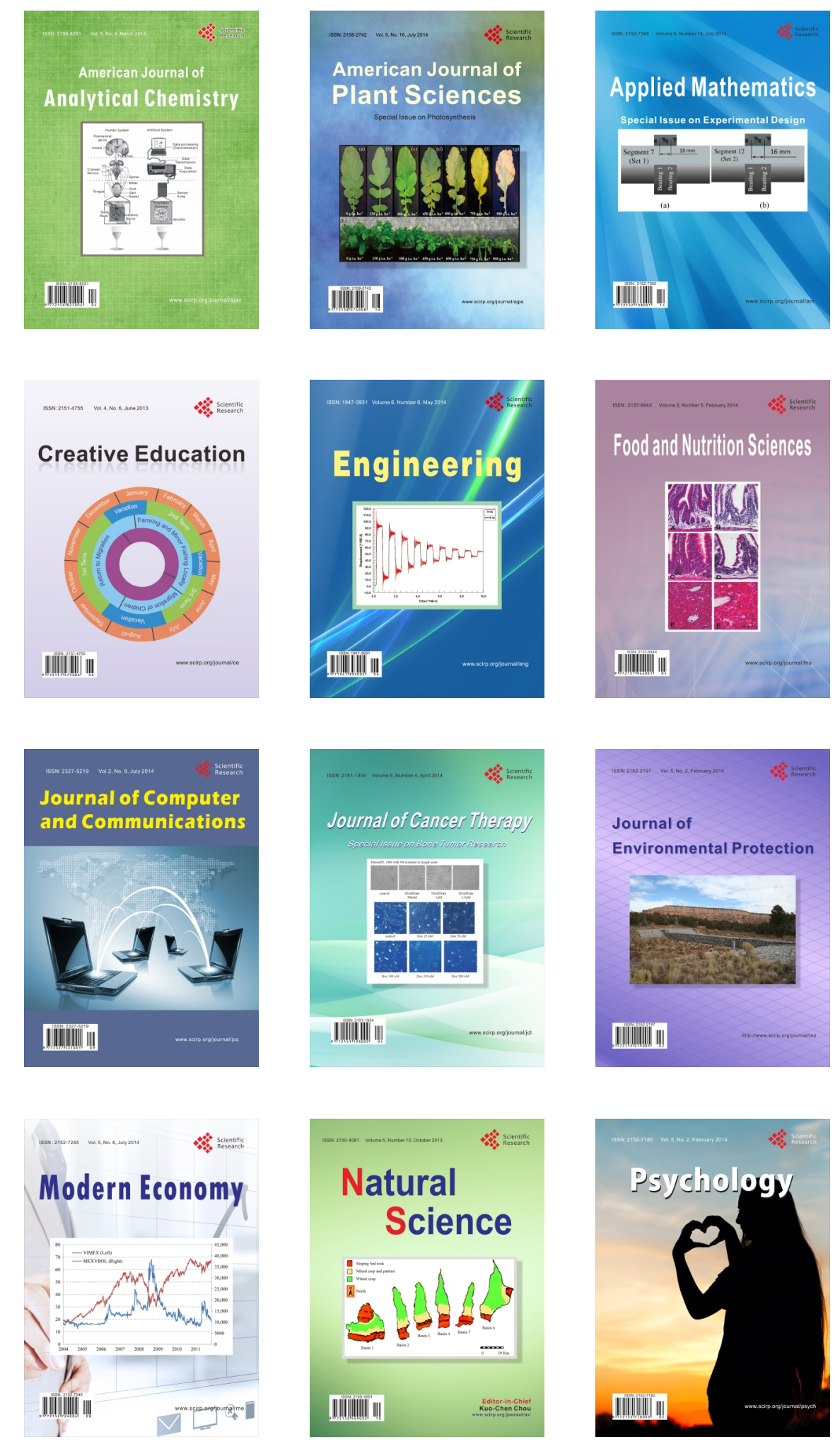